\title{
食品の廃棄と食生活
}

\section{Leftovers, Wasted Food and Eating Habitat}

\author{
堀部 敦子 \\ （農林水産省消費·安全局消費者情報官付食生活改善指導官）
}

\begin{abstract}
An overview of the leftovers and wasted food and our eating habitat is described.
According to the result of Statistics for Loss of Food which includes leftovers and wasted food, published by the Ministry of Agriculture, Forestry and Fisheries in 2002 FY, 5.6 $\%$ of foods consumed in household were leftover or wasted. With these statistics, they also researched the composition of the foods leftover or wested in each food groups, The loss of food consists of mainly vegetables, fruits and marine products, especially an excessive waste of each food group. From statistics in $2000 \mathrm{FY}$, they researched the loss of food in the food service industry. The ratio for food loss in a wedding party reached 23.9 $\%$. The loss of food is one of the main problems of our eating habitat.

To promote better dietary patterns including resolving the problem for wasted food and the more effective use of agricultural resources, the Japanese Government prepared “Japan's Dietary Guidelines" in 2000. In the guidelines, we mentioned "Reduce leftovers and waste through proper cooking and storage methods". In addition, many problems concerning food ssfely have been recognized. Government is promoting "Food Education" now.

To reduce food loss links a solution to a problem for the environment, and is a very important method to review our eating habitat in this era of abundance.
\end{abstract}

\section{はじめに}

平成14年度食品ロス統計調査結果1)によると，世帯に おける食品ロス（食べ残し・廃棄）率は $5.6 \%$ であった. これは食品成分表に示された廃率率を含まないことか ら，簡単に表現すると「食品を無䭾にした」割合を示し ていることになる．

本稿では, 食品の廃棄の現状とその要因, 食品の廃棄 を消減するためにどのような取組がなされているかな ど, 食品の廃棄と食生活について概観したい.

\section{1. 我が国の食品廃棄の現状とその要因}

\section{【食品ロス統計調査結果から見る食品廃棄の現状】}

農林水産省では，平成12年度から食品口ス統計調査を 実施している. 平成 12 年度から 3 年間の同調査結果を図
1 に示す．上述のように，平成14年度の食品ロス率は $5.6 \%$, 内訳を見ると食べ残しと廃棄がほぼ半々であっ た。平成 12 年度から 3 年間の変化を見ると, 調査時期が 平成 12 年度は $8 \sim 9$ 月, 13 年度は $10 \sim 11$ 月, 14 年度は 9

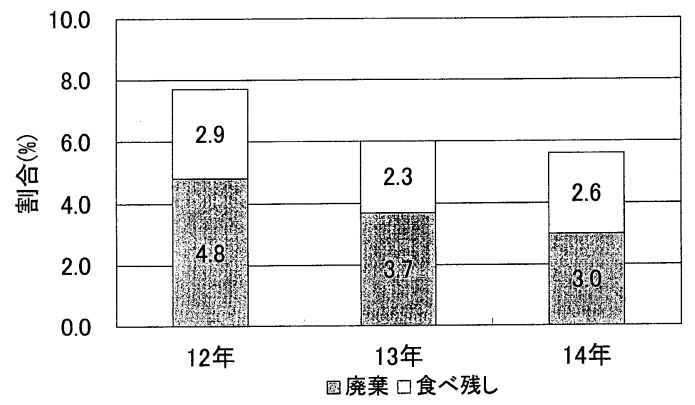

図 1 食品ロス率の変化 
〜10月と調查時期に若干のずれが生じており単純には比 較できないが，年々減少傾向にある，特に，廃棄（賞味 期限切れ等で, 食事において料理・食品として提供され ずに廃棄したものと，可食部分を過剰に廃棄したもの） が減少している状況にある.

この食品ロスについて，世帯属性等の分類により詳し く見ていきたい。

（1）世帯員構成の違いによる相違 食品ロス率を世 帯員構成別に比較したものを図 2 に示した．平成12年度 調査においては，高齢者がいない 3 人以上の世帯で特に
廃棄の量が突出していたものの, 総体的には, 世帯に属 する人数の差による食品口ス率の大幅な差は見られなか った.

（2）食材管理者の年齢による相違 世帯員構成別に みた食品使用量（世帯において調理・契食したもので, 外食, 学校給食等を除いたものに用いる食品の量）及び 食材管理者（食材の購入や調理を主体的に行う者）の年 齢別に見た食品使用量と, 食品口ス率の関係についても 併せて分析した．結果を図 3 に示す。

1 人 1 日当たりの食品使用量は, 平均で $1,213 \mathrm{~g}$ と,

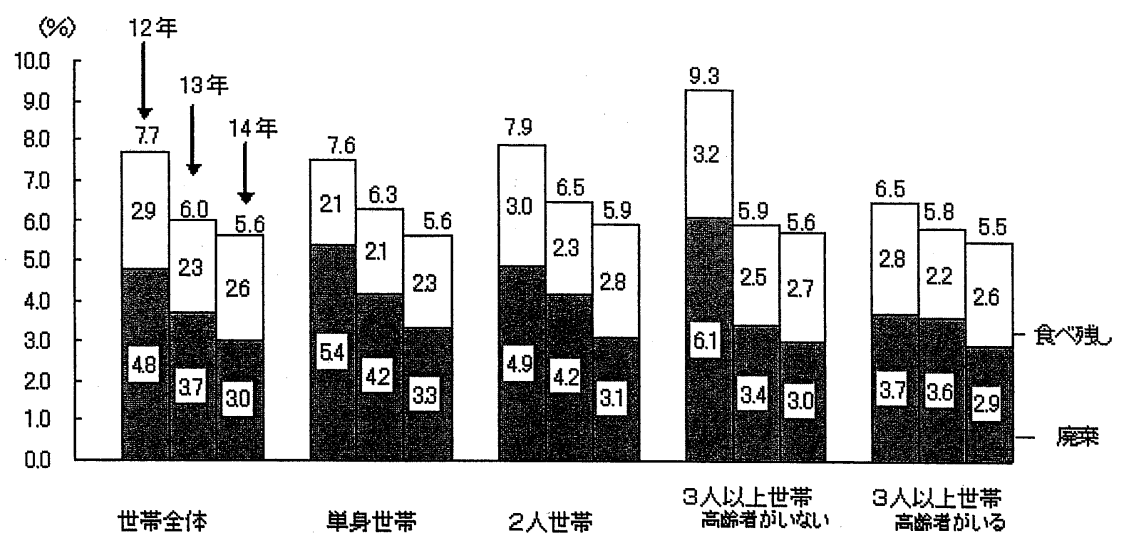

図 2 世帯員構成別食品口ス率

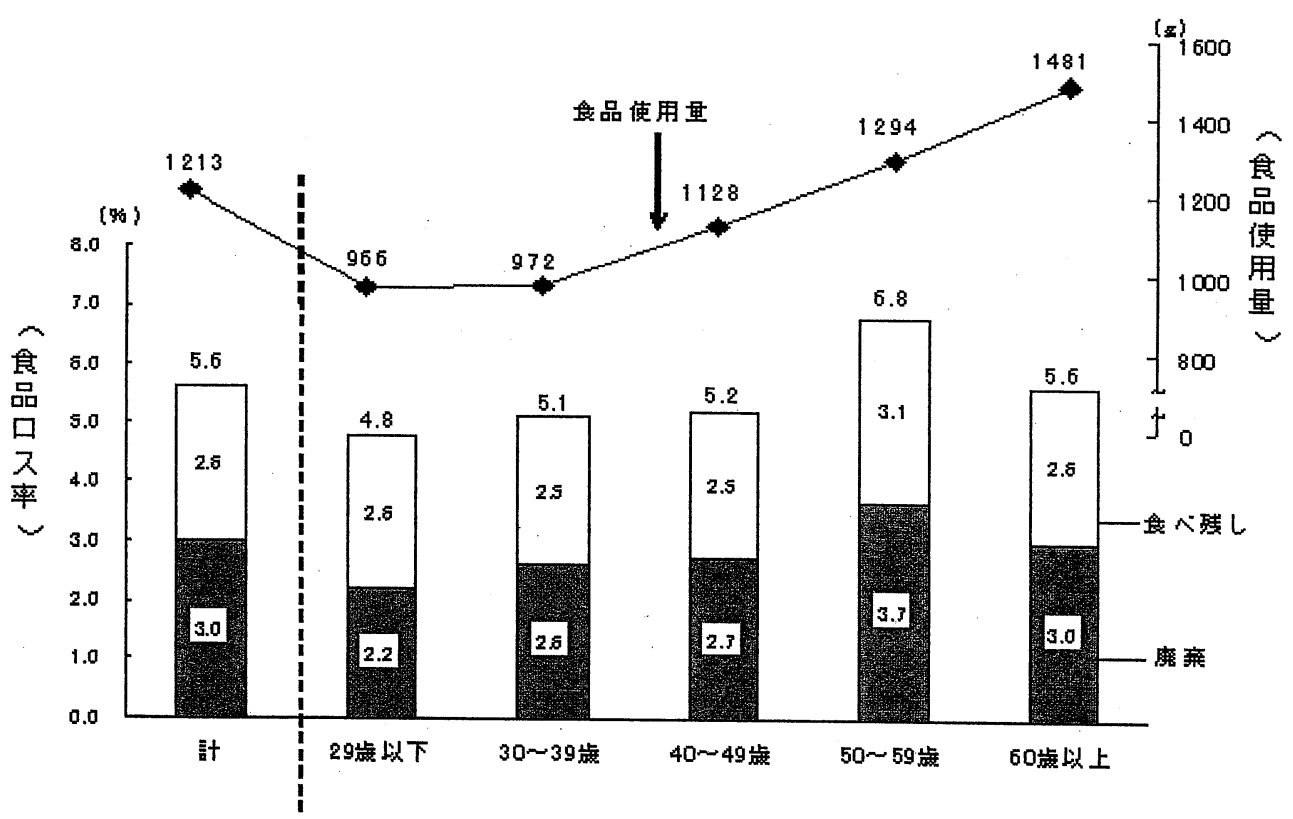

図 3 食品管理者年代別食品使用量及び食品ロス率 
前年に比べ3.8\%増加している．また，世帯員構成別に みると， 2 人世帯において最も食品使用量が多く，3 人 以上世帯で比較的使用量が少ない，更に，食材管理者の 年齢が高まるに従って, 食品の使用量は増加している.

一方，食品口ス率についても，食材管理者の年齢が高 まるに従って上昇していくものの，食事管理者が 60 歳以 上の階層では食品使用量は全階層中最高であるにもかか わらず，50〜 59歳の階層に比べて食品ロス率が減少して いる．この要因は明確ではないが，食品管理者が50～59 歳である場合，労働をしている者も社会的にそれなりの 立場を得ていることから，家庭内で食事を用意していて も，つきあいなどで外食するケースなどが増えて家庭で 食べないケースが増大するとともに，この世代の子ども も大学生，あるいは社会人になり，それまでほど食事の パターンが安定しないのに対し, 食事管理者が60歳以上 である場合，子どもが独立し，また，リタイアする者が 増加することにより，逆に家庭で食事をする頻度が高を るといった家庭構成の変化に伴うライフスタイルの変化 なぞが要因となっている可能性が指摘できよう.

（3）食品口スに占める食品類別の寄与率（図 4) 食品ロスに占める食品類別の寄与率を調べたところ, 最 も多いのは野菜, 次いで果実類, 魚介類といった生鮮食 品が上位を占める一方, 調理加工食品の寄与率も全体の 約 6 分の 1 を占めている.この部分の内訳を見ると，惣 菜・加工品等がそのうち約 8 割を占める.

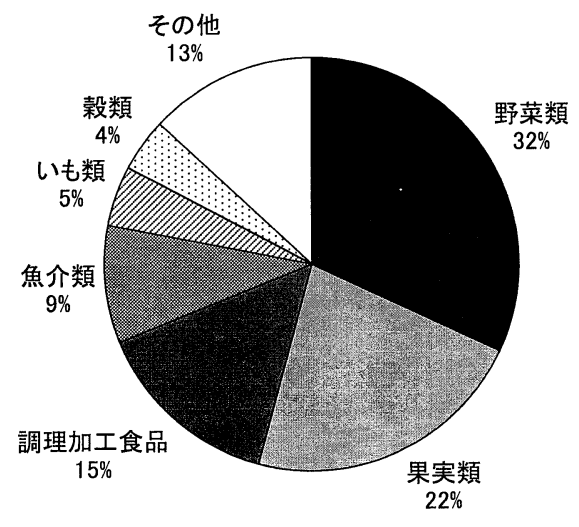

図 4 食品群別口ス寄与率

廃棄の内訳としては，野菜においては，過剩廃棄が最 も多く，次いで食べ残しとなっている，このことから， 皮の剥きすぎなどが主な要因となっていると推察され る. また，果実類においては，食べ残しと過剩廃棄がほ
ぼ同率で並んでいる，生鮮食品においては食べ残しを減 らすことは当然重要であるが，食品の可食部についての 理解を深めた上で，できるだけ過剩廃棄を減らすための 努力が重要である.

一方，加工食品においては，直接廃棄（賞味期限切れ 等により食べられずに廃棄されたもの）が全体の約 6 割 を占めている.このことは，自ら購入したものについて， 購入した後いかに注意を払っていないか，すなわち買っ たけれぞもその事実すら忘れており，後で食品貯蔵場所 を点検して初めてその食材があったことに気づくケース の多さを示していると考えられることから，消費者も日 頃から自らの食事計画に基づく食品購入計画を立てると ともに，買った食品をできるだけ早く消費する心がけが 重要であらう。

（4）外食産業における食品ロス率＼cjkstart平成12年度の食 品口ス統計調査 ${ }^{2)}$ に抢いては, 家庭における食品口ス率 だけでなく，外食産業に打ける食品口ス率についても調 查を行った。な抢，本調查においては，調査上の制約か ら，时房内での廃棄は調查対象には含まれておらず，食 べ残しと作り置き商品の廃棄が対象とされており，その ほとんどが食べ残しである。

業種・形態別の食品ロス率について図 5 に示した．業 種別に見ると，結婚披露宴における食品口ス率は全体の 23.9\%にのぼって抢り，出された食事の概ね 4 分の 1 が そのまま捨てられていることになる，また，結婚披露宴 以外の宴会に抢けるロス率は $15.7 \%$ であり，宴会では豪 華さを重視し，結果的に廃棄されてしまう食品が多いこ とが伺える。

\section{【その他の調査結果から見る食品廃棄の現状】}

（1）家庭ゴミの内訳 平成 9 年に京都市清掃局が行 った「家庭ゴミ組成調査」結果3)によると，1世帯で 1 日に排出される台所ゴミの総量は $758 \mathrm{~g}$ であり，そのう ち $35.7 \%$ にたる $271 \mathrm{~g}$ が可食部分，すなわち食べ残し であったと報告されている（図6）。

さらに，そのうちの約 3 分の 1 に当たる全体の $13 \%$ が 「手つかずの食品」であった，先に述べたように，消費 者が自らの購入した商品についてきちんと把握していれ ば，手つかずの食品が廃棄されることは少なくなるので はないかと考えられる．このような廃棄の形態は消費者 の心がけでなくせるものであり，食生活を考える上で重 要な観点である.

ゴミの問題を考える際には，処分場の問題も考えてい く必要がある。我が国の一般廃棄物は，年間約 5,115 万 トンであり，これは東京ドーム138杯分にも上る．その 
日本食生活学会誌

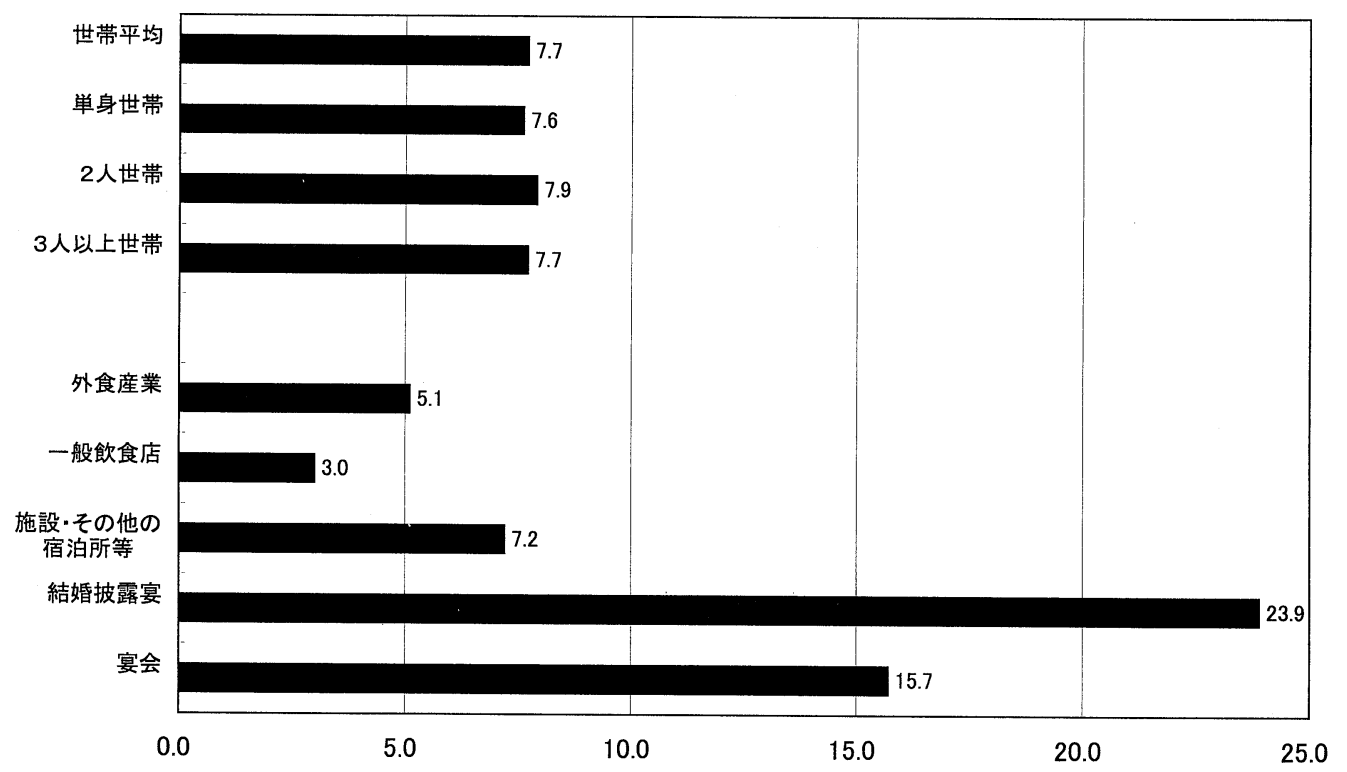

図 5 消費段階における食品口ス率

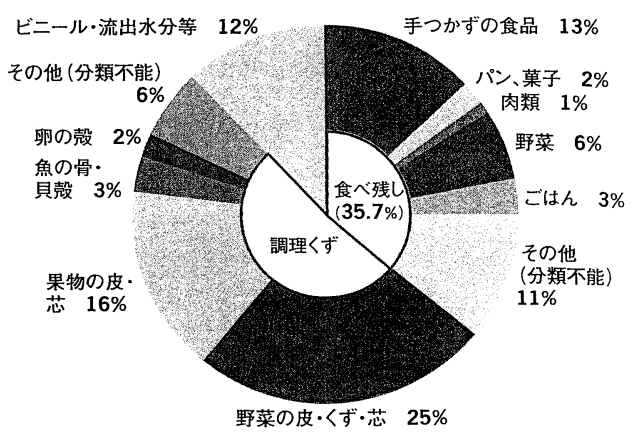

図 6 食べ残し・食品廃棄の状況

うち生ゴミの占める割合は約 $30 \%$ に上っている.ゴミ の排出量全体はここ数年ほぼ横ばいとされているが，一 般廃棄物の最終処分場は，新たな処分場が作られないと なると数年で満杯になることが推測されており，このよ うな最終処分場の残余年数の逼迫という事態の中では, ゴミ全体の減量, 特に自らの心がけで減量できる食品の 廃棄をできるだけ減少させることも重要である.

（2）何故, 食品を捨てたのか?（図 7 ）都市生活

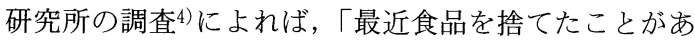
る」と答えた既婚女性は $74 \%$ にもるが，その理由を聞 いた（複数回答）ところ，「古くて食べられない」 $44 \%$, 「賞味期限が過ぎている」37\%,「腐敗・カビ」32\%など が上位の回答となった.これらの理由は, その多くが買
ったにもかかわらず有効に利活用できなかった事実を改 めて浮き彫りにしている.

一方，同じ調査において，食品を買う際には，「『消費 期限』や『賞味期限』にこだわる」としている人も多く, 期限を気にして買っても, 自宅へ持って州ると忘れてし まう現状も伺える.

なお, 食品の期限表示については, JAS 法及び食品 衛生法により言葉の定義が異なったり，そもそも表現が 異なるという実態があったが，「食品の表示に関する共 同会議」(厚生労働省薬事・食品衛生審議会食品衛生分 科会表示部会食品表示調査会及び農林水産省農林物資規 格調査会表示小委員会の共同開催）の報告書5)において， 以下のとおり用語, 定義の統一を図ることが適当である とされた.

賞味期限 : 定められた方法により保存した場合におい て, 期待される全ての品質の保持が十分に可能であると 認められる期限を示す年月日をいう．ただし，当該期限 を超えた場合であっても，これらの品質が保持されてい ることがあるものとする。

消費期限 : 定められた方法により保存した場合におい て, 腐敗, 変敗その他の品質の劣化に伴い安全性を欠く こととなるおそれがないと認められる期限を示す年月日 をいう。

さらに,これらの用語統一の検討過程において, 期限 表示の用語 ·定義の意味についての十分な理解が得られ 


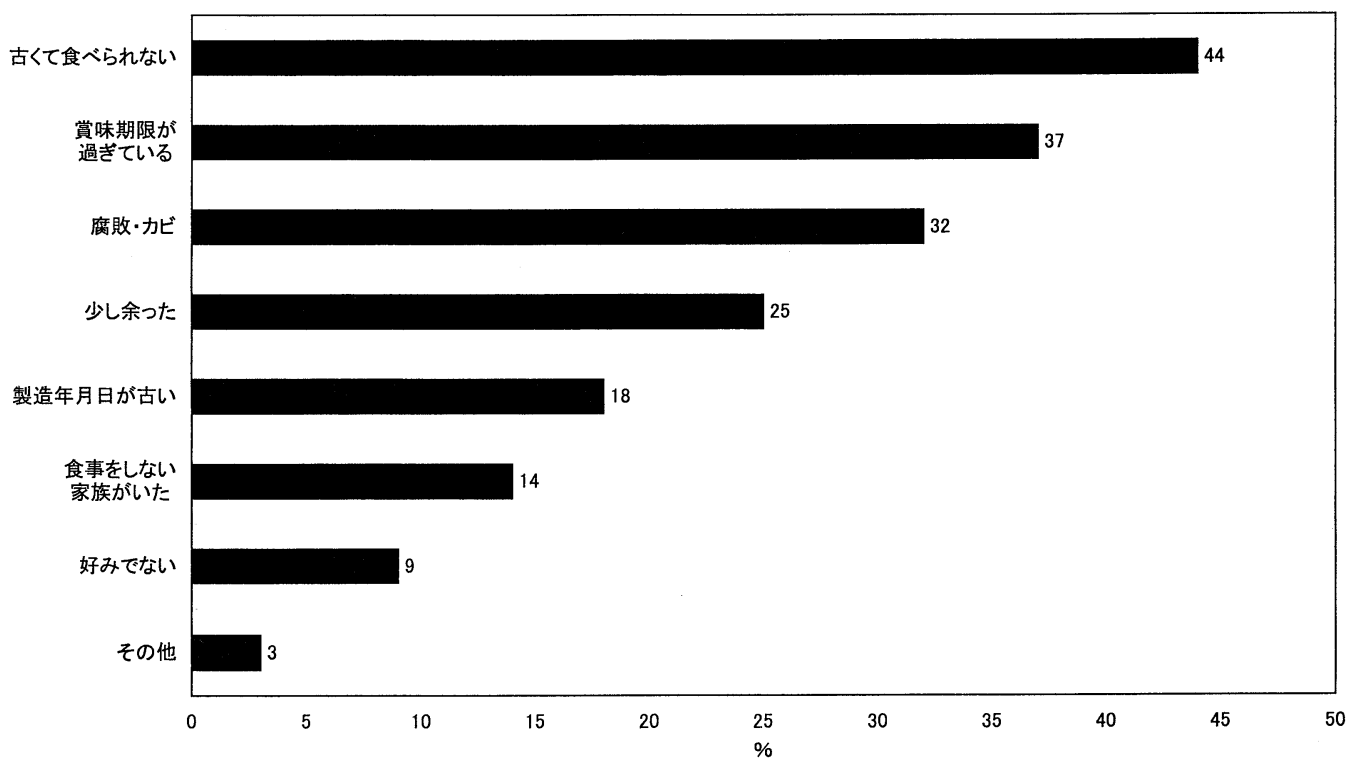

図 7 食品を捨てた理由

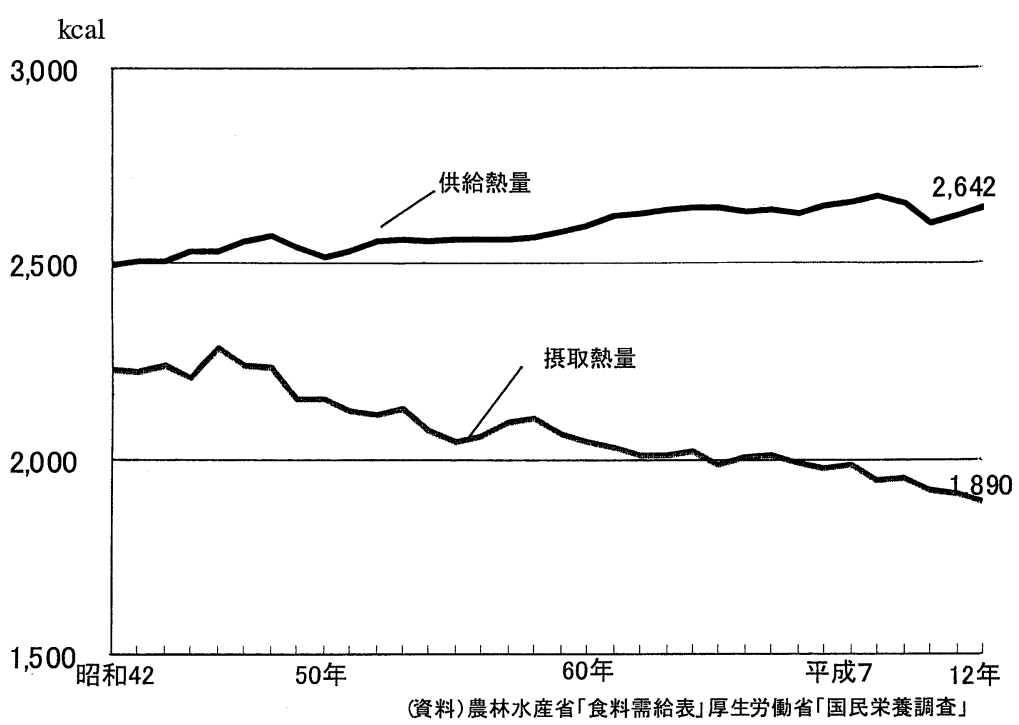

図 8 供給熱量と摂取熱量の推移（一人1日当たり)

ていないことが指摘されており, 定義等について正しい 理解が得られるよう, 消費者及び事業者に対する十分な 情報提供, 普及啓発に努める必要があるとされている. 特に食品の劣化速度が比較的緩やかな食品については, 賞味期限を過ぎても, 直ちに衛生上の危害が生じるもの でないことが知られていないことが多く，このことも， 「賞味期限切れ」を理由とした廃棄の一因となっている
と考えられる.

（3）食品の供給と摂取のアンバランス 厚生労働省 「国民栄養調査」6)及び農林水産省「食料需給表」7)を基に， 供給熱量と摂取熱量の差を比較した（図 8 ). 両者の熱 量の算出方法や統計調査の方法が異なることから, 単純 な比較は困難であるが，平成13年度にはこの差（酒類を 除く）が720kcal となっており，年々その差が拡大する 
傾向にある.すなわち, 食料資源の浪費が年々増加して いることは明白である。

一方, 我が国の食料自給率は $40 \%$ で, 先進国の中で最 低（図 9 ）である7). 裏を返せば, 我が国で供給される 食物の 6 割を海外からの輸入に依存していることにな る. 我が国への食料の供給のために, 海外では我が国の 耕地面積の 2.5 倍を費やしているといわれており，また， 世界中では約 8 億人もの人が飢餓に苦しんでいる現状を 勘案すれば, 我が国における食品廃棄をできるだけ減少 させることにより，食料の海外依存を押さえることは， 我が国の食料自給率向上につながるとともに，世界的な 食糧問題の解決の観点からも極めて重要なことである.

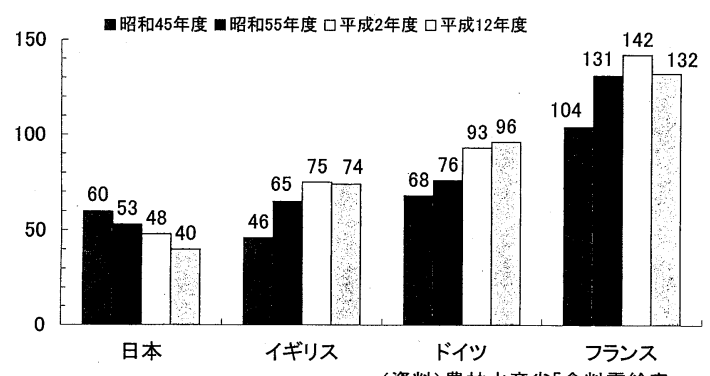

図 9 食料自給率の比較

\section{2.「食生活指針」}

最近の食生活は, 食習慣の乱れや食料の海外依存, 食 べ残しの増加等により, 栄養バランスの偏り, 生活習慣 病の増加, 食料自給率の低下, 資源の浪費など様々な問 題が生じている. このような食生活の様々な問題を解決 していくには，国民一人一人が主体的に自らの食生活を 見直すことが重要である.このような背景を踏まえ, 平 成12年 3 月に, 当時の文部省, 厚生省, 農林水産省の 3 省で「食生活指針」が決定された ${ }^{8)}$.

「食生活指針」は，「食事を楽しみをしょう.」から始 まる10項目で構成されており，その内容は，食事のあり 方, 栄養バランスをはじめとした食事の摂り方, 食習慣 や食文化など多岐に渡っている．この「食生活指針」の 第 9 番目の項目として,「調理や保存を上手にして無駄 や廃棄を少なく.」が挙げられている. 更に, 「食生活指 針」の10項目には，それぞれ $2 \sim 4$ 項目の「食生活指針 の実践のために」という細目が設けられており，第 9 項 目については，「買いすぎ，作りすぎに注意して，食べ 残しのない適量を心がけましょう.」,「賞味期限や消費
期限を考えて利用しましょう.」,「定期的に冷蔵庫の中 身や家庭内の食材を点検し, 献立を工夫して食べをしょ う.」の 3 項目が挙げられている.

飽食といわれる我が国の食生活を見直し, 廃棄を削減 していくために，このような具体的な内容についての実 践を促すことにより, 取組を推進することが重要ではな いか.

\section{3.「食育」の推進}

3 省の連携により策定された「食生活指針」を中心と して, 食生活改善の取組が進められてきたが，2002年 BSE 問題の発生や, その後の食品の偽装表示事件等, 食の安全を摇るがす様々な問題が発生し，消費者の食の 安全性に対する関心が高まってきた．生産側が倫理を守 り, 安全な食品を供給することは当然の責務であるが, 安全や食品を供給されていることを前提として，食に対 する正しい理解に基づく消費者の冷静な行動が一層重要 となっている.

このため, 農林水産省においては, 国民一人一人が自 らの食について考える習慣を身につけ，生涯を通じて健 全で安心な食生活を実現できるよう, 食品の安全性, 食 事と疾病の関係, 食品の栄養特性やその組合せ方, 食文 化や地域固有の食材, 食品廃棄の問題を含む食料消費構 造と食料自給率の関係等を適切に理解するために必要な 情報提供や実践活動を推進していく「食育」を推進して いる(図10).

食育の実践は,国が一方的に推進できるものではなく， 幅広い国民の参加の下に, 様々な場において, 食を巡る 様々な問題について一人一人が考えていくことが重要で ある。

食について改めて考え直す取組を進めることは，とり もなおさず自らの食生活について改めて考えることでめ り，このような取組の中で, 食品の廃棄に関する問題も 解決できるのではないかと期待している.

\section{4. 食品のリサイクル}

食品廃棄の問題を考える上で，もう 1 つの着眼点とな るのが食品リサイクルの観点である.

食品は人間が揸取するものであることを考えると，食 品廃棄物は有害物質を含むふぐの内藏など例外的なもの を除けば，適切な分別をすることにより，これを農業生 産の場に循環することが可能であるという共通の性質を 有しており，古くは，家畜の飼料やたい肥の原料として そのほとんどが農業生産に利用されてくるといった物質 


\section{食事を楽しみましょう。}

・心とからだにおいしい食事を，味わって食べましょう.

・毎日の食事で, 健康寿命をのばしましょう.

·家族の団らんや人との交流を大切に, また, 食事づくりに参加しましょう.

1 日の食事のリズムから, 健やかな生活リズムを.

・朝食で，いきいきした 1 日を始めをしょう.

・夜食や間食はとりすぎないようにしましょう.

・飲酒はほどほどにしましょう。

主食, 主菜, 副菜を基本に, 食事のバランスを.

・多様な食品を組み合わせをしょう.

・調理方法が偏らないようにしましょう。

・手作りと外食や加工食品・調理食品を上手に組み合わせをしょう.

ごはんなどの款類をしっかりと.

・穀類を毎食とって，糖質からのエネルギー摂取を適正に保ちましょう.

・日本の気候・風土に適している米などの穀類を利用しましょう.

野菜·果物, 牛乳·乳製品, 豆類, 魚なども組み合わせて.

・たっぷり野菜と毎日の果物で, ビタミン，ミネラル，食物纎維をとりましょう.

·牛乳·乳製品, 緑黄色野菜, 豆類, 小魚などで, カルシウムを十分にとりましょう.

食塩や脂肪は控えめに.

・塩辛い食品を控えめに, 食塩は 1 日 $10 \mathrm{~g}$ 未満にしましょう.

·脂肪のとりすぎをやめ, 動物, 植物, 魚由来の脂肪をバランスよくとりましょう.

・栄養成分表を見て, 食品や外食を選ぶ習慣を身につけましょう.

適正体重を知り，日々の活動に見合った食事量を.

·太ってきたかなと感じたら，体重を量りましょう.

・普段から意識して身体を動かすようにしをしょう.

·美しさは健康から，無理な減量はやめむしょう。

・しっかりかんで, ゆっくり食べをしょう.

食文化や地域の産物を活かし, ときには新しい料理も.

・地域の産物や旬の素材を使うとともに, 行事食を取り入れながら, 自然の恵みや四季の変化を楽しみましょう.

·食文化を大切にして，日々の食生活に活かしましょう.

・食材に関する知識や料理技術を身につけましょう.

・ときには新しい料理を作ってみましょう.

調理や保存を上手にして無駄や廃棄を少なく。

・買いすぎ，作りすぎに注意して，食べ残しのない適量を心がけましょう.

・賞味期限や消費期限を考えて利用しむしょう.

·定期的に冷蔵庫の中身や家庭内の食材を点検し, 献立を工夫して食べましょう.

自分の食生活を見直してみましょう。

・自分の健康目標をつくり, 食生活を点検する習慣を持ちましょう.

・家族や仲間と, 食生活を考えたり, 話し合ったりしてみましょう.

・学校や家庭で食生活の正しい理解や望をしい習慣を身につけましょう.

·子どものころから, 食生活を大切にしましょう. 


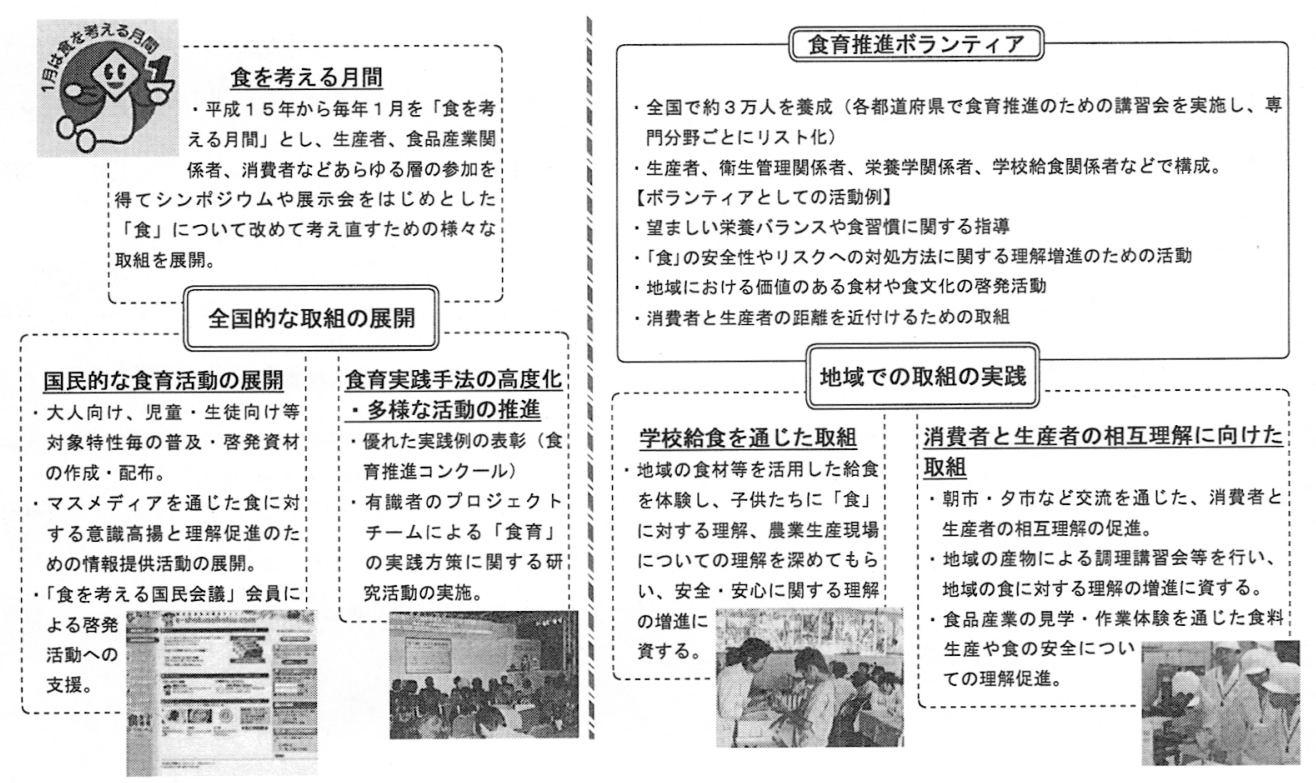

図10 食育の推進

循環が行われてきた。

しかしながら, 高度経済成長の過程において都市化が 進展し, 廃棄物も都市部に偏在して発生するとともに, 食品流通業, 外食産業の都市部を中心とした発達により, これらから生じた食品残さが利用されずに廃棄されると いう現状が生じた. 食品残さの廃棄は, 海外から輸入さ れた窒素を有効活用せずに国内に滞留させることにもつ ながり, 硝酸性窒素による地下水污染問題など, 環境問 題にもつながるのである. まずは発生量全体を抑制する ことが重要であるが, 次善の策として, きちんと分別し た上でリサイクルすることも必要な観点である.

都内にある某ホテルでは, 50 ヶ所ある欴房から毎日約 $5,000 \mathrm{~kg} に も 及 ふ ゙$ 生ゴミが発生する.このホテルでは, これらの全量をコンポストプラントで回収し, 全量をコ ンポスト化した上で, 一次発酵されたコンポストを肥料 工場で更に二次発酵させてたい肥を生産し, 農家に販売 している、農家で生産された野菜は, 再びホテルが買い 上げ，食材として還元利用されている.

この他にも, コンビニエンスストアや，ファミリーレ ストラン等においても, 自社で生ずる廃棄物を分別回収 し, 肥料や飼料として活用する取組が進められている.

農林水産省に扔いても, 省内の食堂で発生する約 270 $\mathrm{kg}$ の生ゴミや，12リットルの廃油のリサイクル取組が 2002年から進められているが，やはり問題となるのはリ
サイクルできるものとリサイクルできないものをきちん と分別して回収できるかどうかにあるようである.

「食品循環資源の再生利用等の促進に関する法律」に おいては, 食品関連業者は, 食品循環資源の再生利用を 促進することとされているが，一方，消費者及び事業者 は, 「食品の購入又は調理の方法の改善により食品廃棄 物等の発生の抑制に努めるとともに, 食品循環資源の再 生利用により得られた製品の利用により食品循環資源の 再生利用を促進するよう努めなければならない.」とさ れている. 本法の中でも, 食品がリサイクルを促進させ るとともに, 食品廃棄物等の発生の抑制に努めることが 重要であると謳われており, 今後の消費者の一層の努力 も必要となってくると考えられる.

\section{おわりに}

環境基本法に基づき策定された環境基本計画において は, 廃棄物・リサイクル対策を「3つのR」をもって推 進することとされている.1つめが Reduce (発生抑制), 2 つめがReuse（再利用），3つめが Recycle（リサイ クル）である，この中でも最も大事なことが Reduce で ある. 消費者一人一人が自らの食生活を見直し, 食品廃 棄を出さないようにすることが重要である.

このためには, 食べきれる量の食材を購入し, 適切に 調理 ·保存すること, 調理技術の向上や様々な調理方法 
の活用などを通じて，できるだけ「無駄を出さない食生 活」を心がけることが重要である.

なお, 本稿では, 農林水産省の統計調査結果等を中心 として, 主に家庭という最終消費段階での食品廃棄の問 題について述べたが, 食生活の外部化が進展し, 外食. 中食への依存率が高まっている今, 外食や中食の調理過 程等での食品廃棄の問題も非常に重要となっている。こ のような問題については, 上述のようにリサイクルに取 り組むなど, 組織での積極的な取組が行われているが, 全体としての状況は必ずしも明らかでない，食品廃棄の 問題を考えていく上で，この点にも留意することが重要 であろう。

\section{参考文献}

1）平成14年度食品口ス統計調查結果の概要 : 農林水産省統計 情報部 (2002)

2）平成 12 年度食品口ス統計調査結果報告 : 農林水産省統計情 報部 (2001)

3）「家庭ゴミ組成調査」: 京都市清掃局（1997）

4）「環境に関する生活者への調査」: 都市生活研究所（1996）

5）期限表示の用語・定義の統一について 報告書 : 食品の表 示に関する共同会議（2003）

6）国民栄養の現状 平成13年度国民栄養調査結果 : 厚生労㗢 省 (2003)

7）我が国の食料自給率一平成 13 年度 食料自給率レポート . 食料需給表一：農林水産省 (2002)

8）食生活指針の解説要領 : 文部省, 厚生省, 農林水産省 (2000)

本稿は，第26回研究集会における特別講演をまとめたものである. 